\title{
ANGKA KEJADIAN LUKA BACOK DI RSUP. PROF. DR. R. D. KANDOU MANADO PERIODE NOVEMBER 2011-DESEMBER 2012
}

\author{
${ }^{1}$ Andrew Malarante \\ ${ }^{2}$ Jan Ngantung \\ ${ }^{2}$ Maximillian Oley \\ ${ }^{1}$ Kandidat Skripsi Fakultas Kedokteran Universitas Sam Ratulangi Manado \\ ${ }^{2}$ Bagian Bedah Fakultas Kedokteran Universitas Sam Ratulangi Manado \\ Email: andrew_tjiang@rocketmail.com
}

\begin{abstract}
Chop wound is a wound caused by sharp or heavy weapon which has at least one sharp cutting edge with powerful energy, so the size of wound same as the length. Generally chop wound happened on region who can be reached by victim hand. This researched purpose to know the description of event rates for chop wound in Surgery Department RSUP Prof. Dr. R. D. Kandou Manado for period November 2011 to October 2012. The study used a retrospective descriptive method by the medical record study in Plastic Surgery Department of BLU RSUP Prof. Dr. R. D. Kandou Manado for period November 2011 to October 2012. There is 52 cases chop wound in this researched. Most of cases dominated by man (84.6\%), with the largest age group are in 21-30 years old. When we take a look more details usually chop wound caused by machete with locations in extremity and also caused tissue damage in the bone and cartilage. Conclusion: Accidents rate due to chop wound more common in young adults, those happened because of drunk and there is dispute in group. These fact required attention from all parties to realize dangers of alcohol use and pay attention to their own safety, so the incidence can be reduced as small as possible.
\end{abstract}

Keywords: Incidence rate, Chop wound, tissue damage.

\begin{abstract}
Abstrak Luka bacok adalah luka akibat benda tajam atau alat berat yang terjadi dengan suatu ayunan disertai tenaga yang cukup besar, sehingga ukuran dalam luka kurang lebih sama dengan panjang dari luka. Luka bacok umumnya terjadi pada daerah yang dapat terjangkau oleh tangan korban. Tujuan penelitian ini untuk mengetahui gambaran angka kejadian penderita luka bacok di SMF Bedah Plastik BLU Prof. Dr. R. D. Kandou Manado periode November 2011 sampai Oktober 2012. Penelitian ini mengunakan metode retrospektif deskriptif melalui penelitian data rekam medik di SMF Bedah Plastik BLU Prof. Dr. R. D. Kandou Manado periode November 2011 sampai Oktober 2012. Keseluruhan luka bacok sebanyak 52 kasus. Kebanyakan kasus terjadi pada pria yaitu sebesar 84,6\%, dengan umur terbanyak 21-30 tahun. Bila dilihat dari penyebab luka sering disebabkan oleh parang dengan lokasi di ekstremitas serta juga menyebabkan kerusakan jaringan pada tulang dan tulang rawan. Simpulan: Angka kecelakaan akibat luka bacok lebih banyak terjadi pada dewasa muda karena salah satu penyebab penggunaan minuman keras berlebih serta adanya perselisihan. Tingginya angka kejadian ini perlu mendapat perhatian dari semua pihak untuk menyadari bahaya penggunaan minuman keras dan memperhatikan keselamatan diri, agar angka kejadian dapat ditekan sekecil mungkin.
\end{abstract}

Kata Kunci: Angka kejadian, luka bacok, kerusakan jaringan. 
Luka adalah hilang atau rusaknya sebagian jaringan tubuh. Keadaan ini dapat disebabkan oleh trauma benda tajam atau benda tumpul, perubahan suhu, zat kimia, ledakan, sengatan listrik, atau gigitan hewan. ${ }^{1}$ Secara umum luka pada kulit terbagi atas luka terbuka dan luka tertutup, dimana luka tertutup dapat terjadi dengan vitalitas kulit yang baik sedangkan luka terbuka terjadi

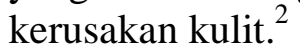

Penyembuhan luka pada kulit melukiskan prinsip-prinsip perbaikan untuk sebagian besar jaringan tubuh. Penyembuhan luka berlangsung secara berurutan melalui fasefase berbagai proses yang saling tumpang tindih seperti: Fase inflamasi yang berlangsung sekitar 3-5 hari, Fase pembentukan jaringan granulasi yang berlangsung sekitar 2-3 minggu, Fase remodeling berlangsung sekitar 1-2 tahun.

Luka kulit secara klasik dinyatakan sembuh melalui proses penyembuhan primer (sedikit sekali pembentukan skar) dan proses penyembuhan sekunder dengan pembentukan skar atau keloid. ${ }^{3}$

Luka pada trauma terjadi sekitar 1,6 juta kasus setiap tahunnya. Laserasi adalah tipe trauma yang sering dijumpai. Kasus laserasi terjadi sekitar 20 juta kasus setiap tahun. Mereka biasanya dirawat di ruang bedah, pusat rawat jalan dan gawat darurat. ${ }^{4}$

Salah satu luka yang disebabkan oleh karena kekerasan benda tajam yaitu luka bacok. Luka bacok umumnya terjadi pada daerah yang dapat terjangkau oleh tangan korban. Tempat yang lazim adalah leher, dada sebelah kiri, pergelangan tangan, dan perut. $^{5,6,7}$

Senjata tajam yang digunakan sebagai alat pembunuhan di Jakarta sekitar 30-40\% dari seluruh kejadian, dan senjata tajam yang digunakan untuk alat bunuh diri sangat jarang (kurang lebih dua kasus setiap tahunnya).

\section{METODE PENELITIAN}

Jenis penelitian yang digunakan dalam penelitian ini adalah retrospektif deskriptif. Subjek penelitian meliputi semua pasien penderita luka bacok yang di rawat di
RSUP Prof. Dr. R. D. Kandou Manado. Tempat penelitian dilakukan di Bagian Rekam Medik RSUP Prof. Dr. R. D. Kandou Manado. Penelitian dilakukan pada bulan Oktober 2012-Desember 2012. Angka kejadian: jumlah penderita dengan luka bacok di bagian bedah RSUP Prof. Dr. R. D. Kandou Manado mulai November 2011-Oktober 2012. Distribusi berdasarkan jenis kelamin pria dan wanita, Distribusi frekuensi menurut umur, Distribusi berdasarkan penyebab, Distribusi berdasarkan lokasi luka, Kerusakan organ terkait.

Alat yang digunakan dalam penelitian Alat Tulis Menulis, laptop, Bahan-bahan referensi, Catatan medik pasien luka bacok di Bagian Rekam Medik RSUP Prof. Dr. R. D. Kandou. Dengan Melakukan konsultasi dengan dosen pembimbing, Mengumpulkan literatur yang berhubungan dengan penelitian, Mengumpulkan data kasus secara retrospektif dari catatan medis korban di bagian bedah dan bagian rekam medic RSU Prof. Dr. R. D. Kandou Manado periode November 2011-Oktober 2012, Melakukan pengolahan data yang kemudian dianalisa berdasarkan hasil presentasenya.

\section{HASIL PENELITIAN}

Data hasil penelitian retrospektif deskriptif penderita luka bacok di Bagian Bedah RSUP Prof. Dr. R. D. Kandou Manado periode November 2011-Oktober 2012, di peroleh data sebanyak 52 kasus. Data yang ada dikelompokkan dalam variabel untuk memudahkan penilaian setiap kasus luka bacok. Variabel tersebut adalah jenis kelamin, umur, penyebab luka, lokasi luka, serta kerusakan organ.

\section{Distribusi penderita luka bacok ber- dasarkan jenis kelamin}

Tabel 1. Distribusi penderita luka bacok berdasarkan jenis kelamin.

\begin{tabular}{ccc}
\hline $\begin{array}{c}\text { Jenis } \\
\text { Kelamin }\end{array}$ & Frekuensi & Presentase \\
\hline Laki-laki & 44 & 84,6 \\
Perempuan & 8 & 15,4 \\
\hline Total & 52 & 100 \\
\hline
\end{tabular}




\section{Distribusi penderita luka bacok berdasarkan umur}

Tabel 2. Distribusi penderita luka bacok berdasarkan umur.

\begin{tabular}{ccc}
\hline $\begin{array}{c}\text { Umur } \\
\text { (tahun) }\end{array}$ & Frekuensi & Presentase \\
\hline $0-10$ & - & - \\
$11-20$ & 14 & 26,9 \\
$21-30$ & 18 & 34,6 \\
$31-40$ & 8 & 15,4 \\
$41-50$ & 7 & 13,5 \\
$51-60$ & 5 & 9,6 \\
$>61$ & - & - \\
\hline Total & 52 & 100 \\
\hline
\end{tabular}

\section{Distribusi penderita luka bacok berdasarkan penyebab luka}

Tabel 3. Distribusi penderita luka bacok berdasarkan penyebab luka.

\begin{tabular}{ccc}
\hline Penyebab & Frekuensi & Presentase \\
\hline Parang & 47 & 90,4 \\
Kapak & 5 & 9,6 \\
\hline Total & 52 & 100 \\
\hline
\end{tabular}

\section{Distribusi penderita luka bacok berdasarkan lokasi}

Tabel 4. Distribusi penderita luka bacok berdasarkan lokasi.

\begin{tabular}{ccc}
\hline Lokasi & Frekuensi & Presentase \\
\hline Temporal & 8 & 15,4 \\
Ekstremitas & 41 & 78,8 \\
Toraks & 3 & 5,8 \\
\hline Total & 52 & 100 \\
\hline
\end{tabular}

\section{Distribusi penderita luka bacok berdasarkan kerusakan jaringan}

Tabel 5. Distribusi penderita luka bacok berdasarkan kerusakan jaringan.

\begin{tabular}{lcc}
\hline \multicolumn{1}{c}{$\begin{array}{c}\text { Kerusakan } \\
\text { Organ }\end{array}$} & Frekuensi & Presentase \\
\hline Epidermis dan Dermis & 52 & 100 \\
Epidermis, Dermis dan & 46 & 88,5 \\
$\begin{array}{l}\text { Fasia } \\
\text { Pembuluh darah besar } \\
\text { (A.ulnaris dan A.radialis) }\end{array}$ & 2 & 3,9 \\
Saraf Besar & 1 & 1,9 \\
(N.ulnaris dan N.medialis) & 24 & 46,2 \\
Otot dan Tendon & 24 & 15,4 \\
Tulang dan Tulang Rawan & 8 & \multicolumn{2}{c}{ Total } & \multicolumn{2}{c}{ kasus } \\
\hline
\end{tabular}

Tabel 1. Menyajikan distribusi penderita luka bacok berdasarkan jenis kelamin, terlihat bahwa laki-laki terbanyak mengalami insiden luka bacok dengan jumlah kasus 44 atau sebesar 84,6\%, sedangkan perempuan hanya delapan kasus atau sebesar 15,4.

Tabel 2. Berdasarkan distribusi penderita luka bacok berdasarkan umur, menunjukkan bahwa insiden terbanyak terjadi pada rentang umur 21-30 tahun dengan jumlah kasus 18 atau sebesar $34,6 \%$, diikuti oleh rentang umur 11-20 tahun sebanyak 14 kasus atau sebesar 26,9\%, selanjutnya umur 31-40 tahun sebanyak delapan kasus atau sebesar 15,4\%, kemudian diikuti oleh rentang umur 41-50 tahun sebanyak tujuh kasus atau sebesar 13,5\%, dan terakhir 51-60 tahun sebanyak lima kasus atau sebesar 9,6\%.

Tabel 3. Menunjukan bahwa insiden luka bacok paling banyak disebabkan oleh penggunaan parang yaitu sebesar 47 kasus (90,4\%), dan yang disebabkan oleh penggunaan kapak sebanyak lima kasus (9,6\%).

Tabel 4. Distribusi penderita luka bacok berdasarkan lokasi menunjukkan bahwa insiden paling banyak terdapat pada lokasi ekstremitas dengan jumlah kasus 41 (78,8\%), selanjutnya di bagian temporal sebanyak 8 kasus (15,4\%), dan di bagian thoraks terdapat sebanyak tiga kasus (5,8\%).

Tabel 5. Distribusi penderita luka bacok berdasarkan kerusakan jaringan ditemukan bahwa seluruh dari kejadian luka bacok mengenai epidermis dan dermis. Dan juga yang terjadi di bagian epidermis, dermis dan Fasia sebanyak 46 kasus atau sebesar 88,5\%, sedangkan di bagian Otot dan Tendon tercatat 24 kasus atau sebesar $46,2 \%$, selanjutnya di bagian tulang dan tulang rawan sebanyak delapan kasus atau sebesar $15,4 \%$, serta ada juga yang mengenai pembuluh darah besar (arteri ulnaris dan arteri redialis) dengan jumlah dua kasus atau sebesar 3,9\% dan saraf besar (nervus ulnaris dan nervus medialis) yang berjumlah satu kasus dari keseluruhan data yang ada dengan presentase sebesar 1,9\%. 


\section{BAHASAN}

Berdasarkan hasil penelitian data rekam medik penderita luka bacok di bagian bedah RSUP Prof. Dr. R. D. Kandou Manado periode November 2011 sampai dengan Oktober 2012, terdapat 52 kasus.

Dalam hasil penelitian didapatkan insiden luka bacok pada laki-laki lebih banyk dibandingkan yang terjadi pada perempuan. Dengan ditemukannya 44 kasus pada laki-laki (84,6\%) dan pada perempuan hanya terdapat delapan kasus (15,4\%). Hal ini diakibatkan oleh karena meningkatnya penggunaan konsumsi minuman keras di Kota Manado yang lebih banyak disalah gunakan oleh kaum lakilaki dari pada perempuan.

Dalam penelitian juga ditemukan insiden terbanyak adalah terjadi pada umur 2130 tahun sebanyak 18 kasus (34,6\%), diikuti rentang umur 11-20 tahun sebanyak 14 kasus serta 31-40 tahun (delapan kasus) menurut data yang terjadi di kota manado. Rentang umur remaja hingga dewasa muda ini lebih sering diakibatkan oleh karena pengendalian emosi yang labil serta penyalahgunaan minuman keras dan juga akibat perselisihan, sehingga dalam rentang umur tersebut lebih banyak ditemukan kasus luka bacok ini dari pada rentang umur lebih tua 51-60 tahun yang hanya terjadi lima kasus atau 9,6\% dalam satu tahun menurut data yang ada. Berdasarkan penelitian Supanardi (2002) di Jakarta, menunjukan bahwa sekitar separuh korban berumur antara 20-39 tahun (47\%) suatu golongan umur yang paling aktif dan produktif.

Luka bacok sering disebabkan karena kekerasan benda tajam yang sering digunakan oleh penduduk itu sendiri, senjata tajam itu dapat berujung tumpul atau lengkung. Seperti dari hasil pada tabel 3, penggunaan parang pada insiden luka bacok menempati tempat pertama dengan 38 kasus (73,1\%) yang disebabkan, sedangkan pisau didapatkan sembilan kasus (17,3\%), serta kapak ditempat ketiga dengan jumlah lima kasus (9,6\%). Menurut Evans (1996), penyebab cedera kepala sekitar 5\% akibat diserang dengan benda tajam (bacok) ${ }^{5,6,11}$
Bila dilihat dari lokasi tersering terjadinya luka bacok pada tabel 4 , luka ini tersering terjadi di bagian ekstremitas dengan hasil data yang diperoleh sebanyak 41 kasus atau sebesar 78,8\% dari seluruh kejadian, sedangkan di bagian temporal terjadi delapan kasus atau sebesar 15,4\%, serta diikuti di bagian toraks dengan jumlah tiga kasus atau sebesar 5,8\%. Di lokasi-lokasi tersebut luka bacok terjadi dikarenakan insiden ini sering terjadi di daerah tubuh yang mana dapat terjangkau oleh tangan, serta tersering di daerah ekstremitas karena hal ini dapat diasosiasikan sebagai luka akibat tangkisan atau perlawanan dari korban. ${ }^{6,7,10}$

Kerusakan jaringan pada luka bacok dari hasil penelitan pada tabel 5, terlihat bahwa semua kejadian luka bacok mengenai bagian Epidermis dan Dermis dengan presentase $100 \%$, serta kerusakan yang terjadi pada daerah epidermis, Dermis dan Fasia dengan jumlah 46 kasus dari seuruh kejadian (88,5\%), yang mengenai Otot dan Tendon tercatat 24 kasus dengan presentase $46,2 \%$, sedangkan yang mengenai bagian tulang dan tulang rawan terdapat delapan kasus dengan presentase sebesar 15,4\%, dan juga ada yang mengenai pembuluh darah besar (dalam hal ini arteri radialis dan arteri ulnaris) dengan jumlah dua kasus (3,9\%), sedangkan yang mengenai saraf besar (nervus ulnaris dan nervus medialis) ditemukan satu kasus (1,9\%) saja dari 52 kasus yang tercatat. Kerusakan pada jaringan yang terjadi pada luka bacok yang disebabkan oleh benda tajam tergantung dari pengguna, berat benda serta kekuatan ayunan dari benda tajam tersebut, sehingga jaringan yang rusak dalam peristiwa ini ditemukan bermacam-macam dari yang ringan hingga berat. ${ }^{5,9}$

\section{SIMPULAN}

Berdasarkan hasil penelitian retrospektif deskriptif penderita luka bacok yang dilakukan di Bagian Bedah RSUP Prof. Dr. R.D. Kandou Manado periode November 2011 sampai Oktober 2012, dapat disimpulkan sebagai berikut: Jumlah kasus luka 
bacok sejak November 2011 sampai Oktober 2012 sebanyak 52 kasus, Insiden terbanyak adalah terjadi pada rentang umur 21-30 tahun Sebagian besar penderita luka bacok adalah, Penyebab luka bacok yang terjadi sering disebabkan oleh parang. Lokasi tersering yang terjadi pada luka bacok terdapat pada bagian ekstremitas dengan presentase 78,8\%. Kerusakan jaringan yang terjadi pada kasus luka bacok ditemukan mengenai seluruh jaringan epidermis dan dermis, sedangkan pada bagian tulang dan tulang rawan dengan jumlah delapan kasus.

\section{UCAPAN TERIMAKASIH}

Diberikan kepada Dr. Nico A. Lumintang, SpB-KL(K) dan Dr. Eko Presetyo, SpBS dan kepada semua pihak yang baik secara langsung maupun secara tidak langsung telah menumbuhkan ide atau gagasan pada penulis sehingga penulis dapat menyelesaikan artikel ini.

\section{DAFTAR PUSTAKA}

1. Sjamsuhidajat R. Luka, trauma, syok dan bencana. Dalam: Sjamsuhidajat R dan Wim de Jong eds. Buku Ajar Ilmu Bedah. Jakarta: EGC, 1997; hal.72-81.

2. Stenens PJM, Bordui F, Van der Weyde JAG. Ilmu keperawatan (Edisi Kedua). Jakarta: EGC, 1992; hal.366.
3. Mitchell, Kumar, Abbas. Dalam: Fausto, Robins dan Cotran. Dasar patologi penyakit (Edisi Ketujuhbelas). Jakarta: EGC, 2008; h.73-5.

4. Driscoll P. Incidence and prevalence of wounds by etiology [homepage on the Internet]. [updated 2009 Dec 13; cited 2012 Oct]. Available from: www.mediligence.com.

5. Sampurna B, Samsu Z, Siswaja TD. Peranan Ilmu Forensik Dalam Penegakan Hukum. Jakarta, Februari 2008; h.127-8.

6. Bagian Kedokteran Forensik. Fakultas Kedokteran Universitas Indonesia. Ilmu kedokteran forensik. h. 42-5.

7. Jones R. Forensic medicine for medical student [homepage on the Internet]. Nodate [cited 2012 Oct]. Available form: http://www.forensicmed.co.uk/ wounds/sharp-force-trauma/choppingwounds/

8. Pieter J. Kulit. Dalam: Sjamsuhidajat R dan Wim de Jong, editor. Buku Ajar Ilmu Bedah. Jakarta: EGC, 1997; h.413-5.

9. Wasitaatmadja SM. Anatomi Kulit. Dalam: Djuanda A, editor. Ilmu Penyakit Kulit dan Kelamin (Edisi Keenam). Jakarta: Fakultas Kedokteran Universitas Indonesia, 1987; h.3-4.

10. Brown $T$ and Devandport $J$. Forensic Science Advanced Investigation. SouthWestern: Cangage learning, 2012; p.203. 